\title{
An Earspool from near Ada, Pontotoc County, Oklahoma?
}

Robert L. Brooks

Unknown

Follow this and additional works at: https://scholarworks.sfasu.edu/ita

Part of the American Material Culture Commons, Archaeological Anthropology Commons, Environmental Studies Commons, Other American Studies Commons, Other Arts and Humanities Commons, Other History of Art, Architecture, and Archaeology Commons, and the United States History Commons

Tell us how this article helped you.

This Article is brought to you for free and open access by the Center for Regional Heritage Research at SFA ScholarWorks. It has been accepted for inclusion in Index of Texas Archaeology: Open Access Gray Literature from the Lone Star State by an authorized editor of SFA ScholarWorks. For more information, please contact cdsscholarworks@sfasu.edu. 


\section{An Earspool from near Ada, Pontotoc County, Oklahoma? \\ Creative Commons License \\ (c) (i) (8)}

This work is licensed under a Creative Commons Attribution-NonCommercial 4.0 International License 


\section{AN EARSPOOL FROM NEAR Ada, Pontotoc County, OKLAHOMa??}

\section{Robert L. Brooks}

\section{Introduction}

Earspools are generally acknowledged as status markers for ranking elites in Caddoan populations occupying the Arkansas River basin as well as the Caddo homelands in the Red River basin. In the Arkansas River basin, Baerreis (1957) and more recently Brown (1996) have discussed the attributes of earspools found at Spiro. There is also documentation for earspools found at other Arkansas River basin sites such as Harlan (Bell 1972) and Huffaker (Baerreis 1954). Earspools at sites reported for the Red River basin include Gahagan (Webb and Dobb 1939) and George C. Davis (Shafer 1973) among others. However, the appearance of earspools at sites outside of the core areas is not well documented. Two exceptions from central Oklahoma are Bell's 1981 discussion of an earspool from the Allcorn site (34ML1) in McClain County and Schaeffer's (1957) description of earspools from the Nagle site in Oklahoma County. This paper reports an earspool from near Ada in Pontotoc County, Oklahoma, examines earlier data pertaining to the presence of Caddoan populations in this area of east-central Oklahoma, and discusses the implications for isolated reports of earspools outside the core culture areas.

\section{The Ada Earspool}

The Ada earspool was found along Springbrook Creek, some six miles northwest of Ada (Figure 1). A landowner originally found the earspool on the Arrowhead Ranch in the 1970s. Following the death of this individual, the earspool was given to an avocational archaeologist from the Oklahoma City area who made it available for study. The Ada earspool is a fragment of a pulley-type with the core perforation area present but most of the inner and outer flange missing (Figure 2). Considering that the general area where the earspool was found has been under cultivation for generations, it may have been broken by plowing activities in the past. Or, perhaps it was broken during its uselife. The incomplete nature of the earspool makes detailed analysis impractical. However, some general observations are possible. Like many of the earspools found within the Arkansas River basin and peripheral areas, it is made of fine grain sandstone. In fact, many of these earspools appear to be so similar in material that they may come from a common source. The Ada earspool retains green staining indicative of copper mineral salts even after being exposed on the surface for an unknown number of years. As noted above, the earspool is a pulley design with a central perforation. Decoration on the earspool appears to represent the cross pattern although the absence of the outer flange limits knowing whether the edge had some sort of decoration. Baerreis (1957) and Brown (1996) have documented a progressive development in earspools through time. Earlier earspool forms are unperforated and undecorated. Later versions are perforated but undecorated with the final version including perforations as well as decoration. Based on this progression, the Ada earspool represents the latest version. Bell (1981) described a similar earspool from the Allcorn site (34ML1) north of Purcell, Oklahoma and suggested that it would date to around A.D. 1200. The earspool found near Ada also appears similar to ones from the Nagle site (34OK4), an Arkansas River basin Caddoan cemetery northeast of Oklahoma City that dates to circa A.D. 1200 (Shaeffer 1957). 


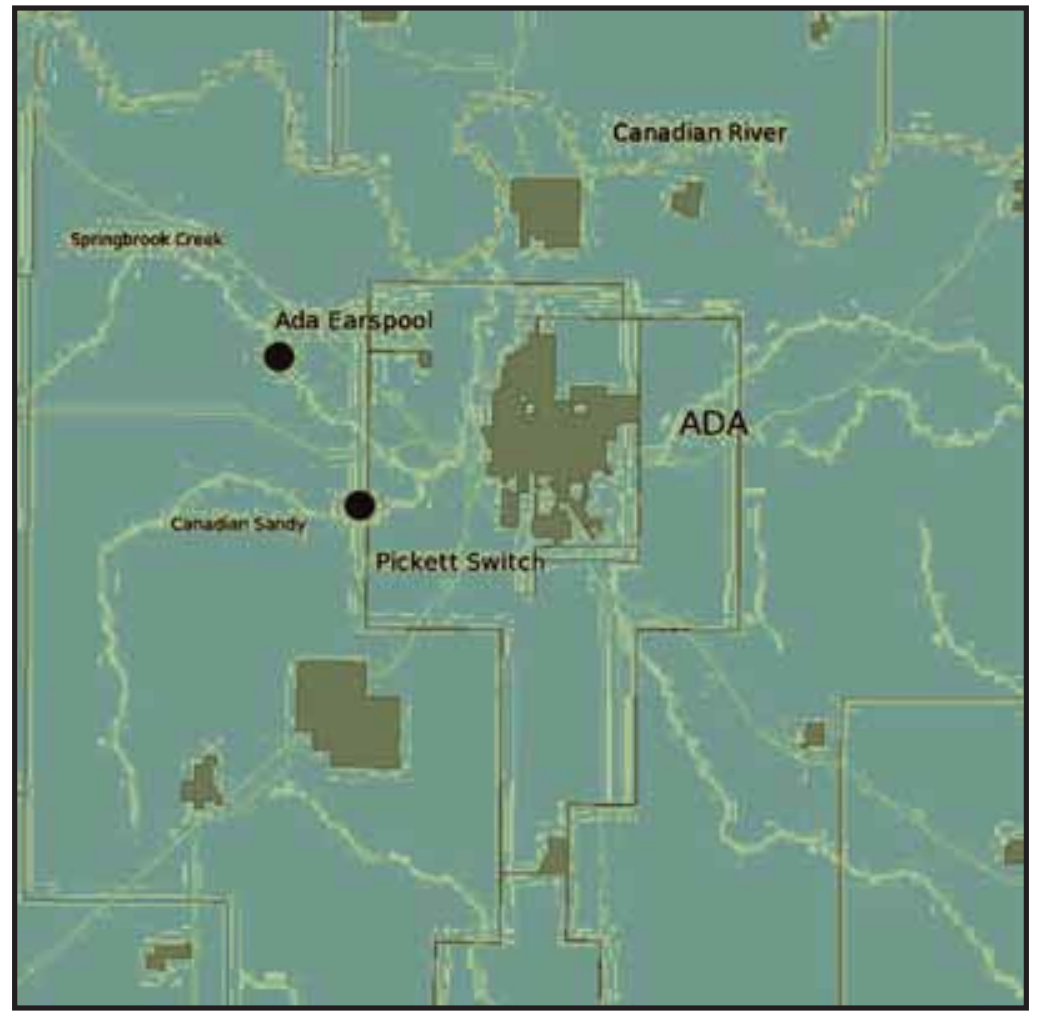

Figure 1. Map of Ada vicinity showing relative location of earspool and Pickett Switch site.

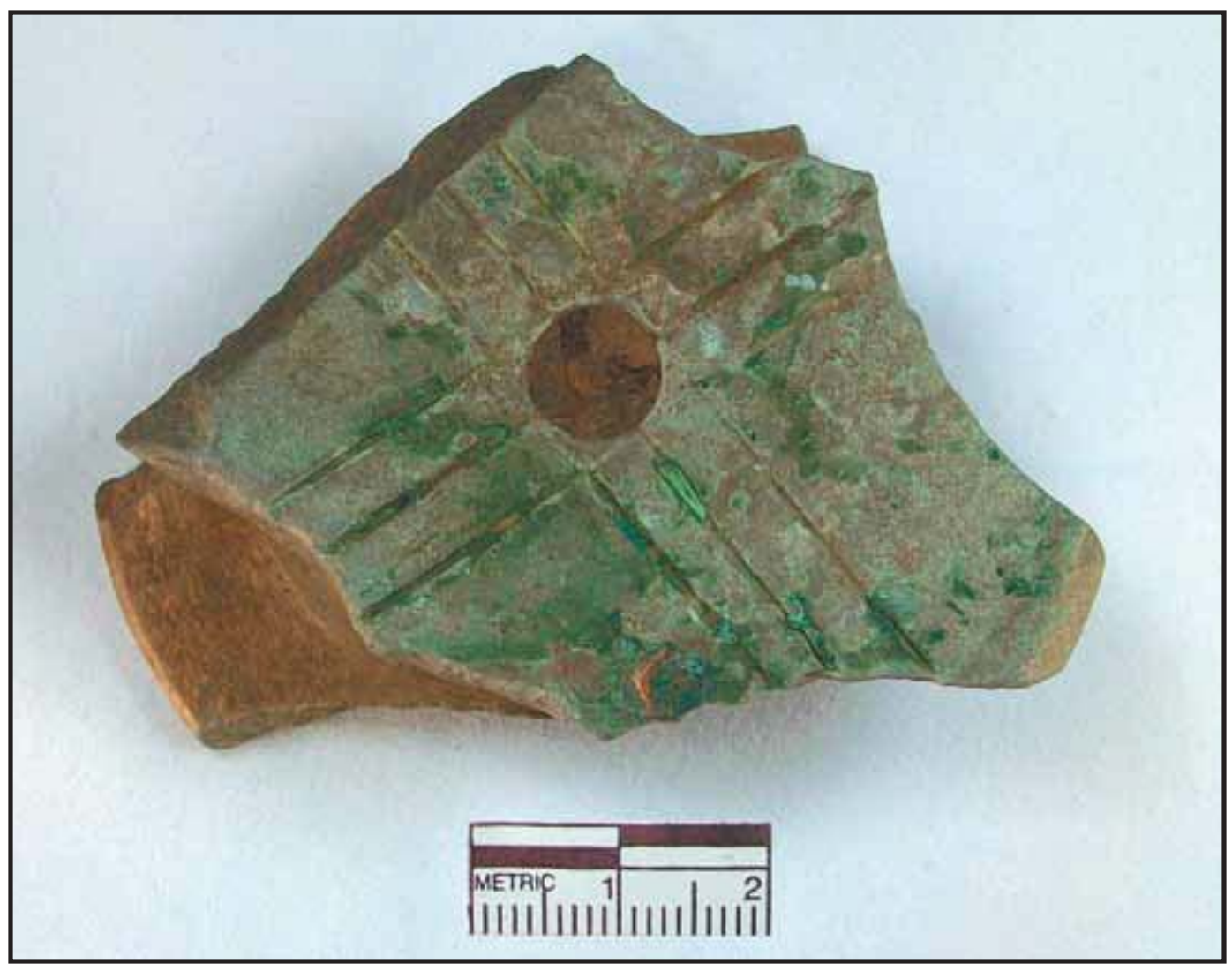

Figure 2. Earspool fragment from Arrowhead Ranch near Ada, Oklahoma. 


\section{Evidence of Caddoan Occupation in East-Central Oklahoma}

There is some evidence for the presence of mound building Caddoan people in east-central Oklahoma. The evidence is intriguing and also contentious. H. R. Antle, a math teacher from nearby Sulphur, Oklahoma investigated a number of sites in the Ada vicinity in the 1930s (Albert 1984). Mr. Antle had no professional training as an archaeologist and his study of these sites was more unsystematic digging than measured excavation. To his credit, he made efforts to document his findings and also report on his work. The principal site bearing on possible Caddoan occupation of the area is Pickett Switch (34PN1). Pickett Switch is located at the juncture of an intermittent stream and Canadian Sandy Creek (Figure 1). Antle (1934) initially dug at the Pickett Switch site in 1930 with assistance from the Boy Scouts. However, after reading of Joseph Thoburn's investigations, he halted work until he could learn more of proper archaeological procedures (although Thoburn was not necessarily the best teacher). He returned to work on Pickett Switch in 1933 and continued his studies of this site and others in Pontotoc County into the early 1940s. Antle reported a number of mounds at the site that he thought represented earth lodges. His work in 1930 and in 1933 revealed what he described as grass structures, some of which had been burned and contained the remains of adults and children. He assumed that the remains represented victims of a raid by another prehistoric group. There did not appear to be funerary offerings with the individuals and Antle characterized the ceramics as unsophisticated bowls and gourd shaped vessels. However, a photo of artifacts retrieved from one or more of these structures clearly illustrate a Caddoan water bottle that appears highly polished. He makes no mention of color treatment so it is assumed that these are not red-slipped. The water bottle may be Spiro Engraved or a similar style. Bowls are not characteristic of Plains Village ceramics assemblages and it is difficult to envision what ceramic type these may have represented.

O. C. Walz and Kenneth Campbell of East-Central University (Ada) subsequently worked at the Pickett Switch site during a period extending from November 1956 through January 1957 (Shaeffer 1956a, Shaeffer 1956b). Dr. Bell, Oren Evan, William Lipe, and McKay Gibson (as well as James Shaeffer) visited the East-Central University investigations twice during this period. Based on their field observations, there were clearly structures of circular construction with evidence of two center posts and possibly grass walls. The structures uncovered by the East-Central University researchers (Campbell was the Curator of the Museum) also were burned and contained human remains. Although currently the Pickett Switch site is assumed to represent a Plains Village occupation, Shaeffer (1956a: 5) in viewing the ceramics from the site stated that they were unlike those of the Washita River focus.

Antle also dug at another village site (which has not been rediscovered) some five miles east of Pickett Switch on Little Sandy Creek (Antle 1935). Features at this site had been exposed by sand quarrying operations leaving large areas of graded surfaces for Antle to explore. He identified a number of bell shaped refuse (cache) pits some three feet in diameter and three to four feet deep in this village area that extends some distance along the terrace above the creek. These cache pits were described as containing ash, burned soil and wood, and an abundance of animal bone although only deer and box turtle were specifically mentioned. Antle also described a structure that he characterized as a grass earth lodge some 40-50 feet in diameter. Ceramics found in the cache pits and amidst the debris from the structure are cord-impressed. The relationship between this site and Pickett Switch is unclear.

Antle provided a few other hints of Caddoan occupation from the Ada vicinity. In an article for American Antiquity, he describes an incised piece of copper that was found in association with shell-tempered pottery at a rockshelter in southern Pontotoc County (Antle 1942: 402). Antle, in his 1935 report on the site adjacent to Little Sandy Creek also mentions another location with a mound three feet high and 60 feet in diameter. The location of this mound is unknown and we also do not know whether Antle ever explored its contents. 
Clearly, these reports suggest a Caddoan occupation of the Ada area that extends beyond the earspool fragment found on Springbrook Creek. Considering that the Canadian River drainage is only about five miles north of Ada, it is certainly plausible that Arkansas River basin Caddoans could have traveled upstream to this area-with the knowledge that they traveled further west to the Purcell area by around A.D. 1200 (Brooks 2010).

\section{The Social Implications of Earspools}

Earspools served as status markers beginning in the Woodland period and continuing into Mississippian times. They are prominently portrayed in the engraved shell iconography from Spiro (Phillips and Brown 1989). While it can be demonstrated that earspools were a widespread item of status distinction and that both sexes wore them (Shafer 1973), there are aspects of earspools that remain poorly understood. For example, do they connote specific rank that falls outside of lineage society or are they restricted to certain lineage groups? Do you have to obtain a certain age before earspools can be worn? Are they worn all the time or only during certain ceremonial events? These questions remain to be explored. But, it also appears that earspools, being indicators of status, were not items that were transferable. By this, I mean that Caddoans would not give earspools to non-Caddoans or to Caddoans of lesser status. An examination of funerary offerings at Plains Village cemeteries in south-central and west-central Oklahoma found no evidence of earspools. We can assume that finding earspools at a site in the region indicates the presence of Caddoan elites. The earspool from the Springbrook Creek area points to a Caddoan group's presence. [It is doubtful that they (the elites) would travel alone to east-central Oklahoma.] This may be further substantiated by reexamination of Antle's work at the Pickett Switch site. Certainly, sites in the Ada area merit further study, as do collections at EastCentral University from Antle's and Walz and Campbell's excavations.

\section{References Cited}

Albert, Lois E.

1984 Survey of Archaeological Activity in Oklahoma. In Prehistory of Oklahoma, edited by Robert E. Bell, pp. 45-64, Academic Press, Orlando.

Antle, H. R.

1934 Excavation of a Caddoan Earth Lodge. Chronicles of Oklahoma 12(4): 443-446.

1935 Report of an Archaeological Site. Chronicles of Oklahoma 13(2):191-196.

1942 A Southern Oklahoma Copper Ornament. American Antiquity 7:402.

Baerreis, David A.

1954 The Huffaker Site. Bulletin of the Oklahoma Anthropological Society 2: 35-48.

1957 The Southern Cult and the Spiro Ceremonial Complex. Bulletin of the Oklahoma Anthropological Society 5:23-38.

Bell, Robert E.

1972 The Harlan Site, Ck-6, A Prehistoric Mound Center in Cherokee County, Eastern Oklahoma. Oklahoma Anthropological Society Memoir 2.

1981 A Stone Earspool from the Allcorn Site, McClain County, Oklahoma. Newsletter of the Oklahoma Anthropological Society 29(5):10. 


\section{References Cited (cont.)}

Brooks, Robert L.

2010 The Allcorn Site (34ML1) and the Nagle Site (34OK4), and Their Relationship to the Arkansas River Caddoan Area. Paper presented at the $52^{\text {nd }}$ Annual Caddo Conference, Tyler, Texas.

Brown, James A.

1996 The Spiro Ceremonial Complex: The Archaeology of Arkansas Valley Caddoan Culture in Eastern Oklahoma. Memoirs of the Museum of Anthropology, University of Michigan, Ann Arbor.

Phillips, Phillip and James A. Brown

1978 Pre-Columbian Shell Engravings from the Craig Mound at Spiro, Oklahoma. Peabody Museum Press, Peabody Museum of Archaeology and Ethnology, Harvard University, Cambridge, Massachusetts.

Shaeffer, James A.

1956a News- East Central College Excavations. Newsletter of the Oklahoma Anthropological Society 5(5):5.

1956b East Central State College Dig. Newsletter of the Oklahoma Anthropological Society 5(7):4-5.

1957 The Nagle Site, Ok-4. Bulletin of the Oklahoma Anthropological Society 5:93-100.

Shafer, Harry

1973 Lithic Technology at the George C. Davis Site, Cherokee County, Texas. Ph.D. dissertation, Department of Anthropology, University of Texas, Austin.

Webb, Clarence and Monroe Dodd

1939 Further Excavations at the Gahagan Mound: Connections with a Florida Culture. Bulletin of the Texas Archeological and Paleontological Society 11:90-128. 